\title{
Physicochemical parameters associated with the methods of application of salt baths and their field assessment of blood parameters of Atlantic salmon in water pre-smolt stage
}

\author{
Parámetros físico-químicos del agua asociados a los métodos de aplicación de baños \\ de sal y su evaluación en terreno sobre parámetros sanguíneos de salmón del atlántico \\ en etapa pre-smolt
}

\author{
V González ${ }^{\mathrm{a}}$, BS Labbéa, V Valerio ${ }^{\mathrm{b}}$, L Vargas-Chacoff ${ }^{\mathrm{c}}$, \\ D Martínez ${ }^{\mathrm{c}}, \mathbf{R}$ Oyarzún ${ }^{\mathrm{c}}, \mathrm{JLP}$ Muñoz ${ }^{\mathrm{a}^{*}}$
}

\begin{abstract}
Salt baths in the production system of salmonids in fresh water, are important for the prevention and control of different diseases such as saprolegnia fungus. This standard procedure generates a rapid depletion of $\mathrm{O}_{2}$ in the water, leading to a significant increase of $\mathrm{CO}_{2}$, affecting blood parameters associated with animal welfare, such as $\mathrm{Na}^{+}, \mathrm{Cl}^{-}$, glucose and protracted hypercarbia. The aim of this study was to evaluate the response field of blood parameters related to fish welfare and the physical-chemical parameters of water to which they are subject during this period, comparing two sets of bath salt. One group of farmed Atlantic salmon (Salmo salar) in the pre-smolt stage was exposed in a salt bath system with the usual conditions and a second to a recirculation system with a waterfall for degasification, with two different exposure periods of one and two hours. The results of the concentration of $\mathrm{CO}_{2}$ in the water show significant variations between the two systems without recirculation compared to the control condition and salt. Significant differences were observed between the recirculating system and the control in blood levels of $\mathrm{pCO}_{2}$ and $\mathrm{HCO}_{3}$, but not $\mathrm{pH}$. Our field data also show that salt baths that are performed regularly at the fish farms generate significant effects on blood parameters associated with animal welfare specifically fish $\mathrm{pCO}_{2}$ and $\mathrm{HCO}_{3}$ causing minor hypercarbia without generating blood acidosis. The addition of water recirculation with a waterfall does not affect blood parameters.

Key words: salt bath, water chemistry, saprolegnia, animal welfare.
\end{abstract}

RESUMEN. Los baños de sal, dentro del sistema productivo de salmónidos en agua dulce, son un paso clave en la prevención y el control de diferentes enfermedades como la saprolegnia. Este procedimiento habitual genera un agotamiento rápido del $\mathrm{O}_{2}$ en el agua, lo que genera un aumento significativo del $\mathrm{CO}_{2}$ en el agua, afectando parámetros sanguíneos asociados a bienestar animal, como $\mathrm{Na}^{+}, \mathrm{Cl}^{-}$, glucosa y en situaciones prolongadas hipercapnia. Este trabajo tiene como objetivo evaluar en terreno la respuesta de parámetros sanguíneos asociados a bienestar de los peces y parámetros físico-químicos del agua a la que están sometidos en este periodo, comparando dos sistemas de baño de sal. Para ello se sometió a un grupo de Salmo salar en etapa pre-smolt a un baño de sal habitual, otro grupo a un sistema de recirculación con cascada de agua para su desgasificación y un grupo control sin sal, exponiéndolos a diferentes periodos de una y dos horas. Los resultados de la concentración de $\mathrm{CO}_{2}$ en el agua muestran variaciones significativas entre ambos sistemas con y sin recirculación para la condición control y con sal. Los niveles sanguíneos evaluados en terreno de $\mathrm{PCO}_{2}$ y $\mathrm{HCO}_{3}$ presentaron diferencias significativas respecto del sistema con recirculación y al control, no así los niveles sanguíneos de $\mathrm{pH}$. Nuestros datos de terreno demuestran que los baños de sal que se realizan con regularidad en los centros de cultivo generan efectos significativos sobre parámetros sanguíneos asociados a bienestar animal de los peces, específicamente $\mathrm{PCO}_{2} \mathrm{y} \mathrm{HCO}_{3}$, provocando hipercapnia leve sin generar acidosis sanguínea, al añadir recirculación del agua con una cascada a los baños de sal, no se ven afectados los parámetros sanguíneos.

Palabras clave: baño de sal, química del agua, saprolegnia, bienestar animal.

\section{INTRODUCTION}

In recent years, animal welfare has become an increasingly relevant subject for consumers and regulatory authorities in various countries, and the importance of animal welfare in the aquaculture industry has consequently

Accepted: 14.01.2016.

${ }^{a}$ Centro i mar, Universidad de Los Lagos, Puerto Montt, Chile.

${ }^{b}$ Salmones FrioSur S.A, Puerto Montt, Chile.

'Instituto de Ciencias Marinas y Limnológicas, Facultad de Ciencias, Universidad Austral de Chile, Valdivia, Chile.

*Corresponding author: JLP Muñoz; casilla 577, Puerto Montt, Chile; joseluis.munoz@ulagos.cl grown (Hastein 2004). Animal welfare is particularly applicable to the aquaculture industry given the existing relationship between stressful situations and poor immune system responses in cultivated fish, which provokes increased rates of pathogenic infection (Dhabhar 2009, Tort 2011, Vargas-Chacoff et al 2014). There are a wide variety of stressful stimuli in salmonid farming, among which, animal management and confinement are the most significant (Kestin 1994). Confinement stress resulting from high stock density is produced due to a reduced water volume where fish are held, causing a social response and increased physiological activity (Thomas et al 1999). In turn, management procedures, such as vaccination, sanitary baths, transport, and taking biometric measurements, 
activate biochemical processes associated with the stress response (Gesto et al 2013).

In salmon farming, there are two types of stress responses. The first is an acute response to short-term events, such as fish capture and handling, biometric analyses, and transport. The second is a chronic response to persistent, long-term conditions such as high stock density, variations in water quality, exposure to new environments, social dominance, and exposure to certain diseases (Wendelaar Bonga 1997, Polakoff et al 2006, Tort 2011, Vargas-Chacoff et al 2014). Salt baths are one of the management procedures used by the aquaculture industry. These baths are generally administered in non-circulating tanks, generating rapid $\mathrm{O}_{2}$ depletion in the water, a significant increase in $\mathrm{CO}_{2}$ concentration, and a consequent $\mathrm{pH}$ decrease (Auro de Ocampo and OcampoCamberos 1999). In goldfish (Carassius auratus), salt baths can significantly affect blood parameters, such as $\mathrm{Na}, \mathrm{Cl}$, and glucose, depending on the salt concentration and exposure time (Burgdorf-Moisuk et al 2011).

In the culture of freshwater fish, salt baths are commonly used to treat pathogens such as Flavobacterium and Saprolegnia sp (Rasowo et al 2007, Mifsud and Rowland 2008, Wangen 2012). Saprolegnia sp are oomycete fungi more closely related to chromophyte algae than other fungi, meaning that the fungicides used for the control of this genus are ineffective (Avendaño 2012). Saprolegnia sp is both primary and secondary, or opportunistic, pathogens that can infect completely healthy salmon or dead tissue. Saprolegniosis was for a long time kept under control using green malachite. However, the use of this carcinogenic chemical compound is now prohibited (Mifsud and Rowland 2008, Avendaño 2012). Currently, salt is still used as an effective control method against saprolegniosis. Salt baths typically last one hour and employ concentrations between 1.5-3.0\%, with oomycetes of Saprolegnia sp unable to proliferate at $\mathrm{NaCl}$ concentrations greater than $1.75 \%$ (Avendaño 2012, Wangen 2012). On the other hand, low concentration salt baths counterbalance the osmotic stress produced by cutaneous lesions by preventing electrolyte loss (Van West 2006, Wangen 2012).

The objectives of the present study were to evaluate the effects of salt baths in the field on the physicochemical parameters of the water and how these would impact blood parameters associated with the welfare of pre-smolt Atlantic salmon (Salmo salar). To achieve these aims, two salt bath systems for the control of Saprolegnia sp. were evaluated in the field using the i-STAT equipment to determine variations in the physicochemical properties of the water and in blood parameters (i.e. glucose, $\mathrm{Na}^{+}, \mathrm{K}^{+}$, $\mathrm{Cl}^{-}, \mathrm{pH}, \mathrm{PCO}_{2}, \mathrm{HCO}_{3}$ ).

\section{MATERIAL AND METHODS}

Pre-smolt $S$. salar salmon were acquired from a fish farm located in Hornopirén of the Lakes Region, Chile (Salmones FrioSur S.A.). The samples were translated to the bioassay laboratory of the same farm and were randomly distributed among eight tanks $\left(0.9 \mathrm{~m}^{3}\right)$ at a density of $5.2 \mathrm{~kg} / \mathrm{m}^{3}(\mathrm{n}=350$ fish weighing $110 \pm 5 \mathrm{~g}$ per tank).

This study was performed in the field and within the framework of a Salmones FrioSur S.A. Salt Bath Improvement Program.

The fish were acclimated for ten days and were fed daily with a Golden Activia de Biomar diet in proportion to $1 \%$ corporal biomass. Prior to administering the treatments, the fish were maintained under fasting conditions for two days. The experimental treatments consisted in the following: i) a traditional salt bath with a closed water recirculation system (CS) and ii) a salt bath with an open water recirculation system (OS). The OS included a waterfall design to provide greater oxygenation and to extract $\mathrm{CO}_{2}$ from the water. Both systems (CS and OS) without the addition of salt were used as controls. Each treatment and control were evaluated in duplicate.

Prior to salt bath administration, each treatment was saturated with oxygen $(100 \%)$. Once the salt bath assay began, the following parameters were measured every 20 minutes in all groups: dissolved Oxygen $(\mathrm{mg} / \mathrm{L})$, measured with an oxygenometer (OxyGuard Handy Polaris); $\mathrm{CO}_{2}$ $(\mathrm{mg} / \mathrm{L})$, determined with a portable device $\left(\mathrm{OxyGuard} \mathrm{CO}_{2}\right)$, temperature $\left({ }^{\circ} \mathrm{C}\right)$, conductivity $(\mu \mathrm{S} / \mathrm{cma})$, and salinity and $\mathrm{pH}$, which were measured with a multiparameter meter (HANNA HI 9828). As a security measure, if the dissolved oxygen levels fell below $7.5 \mathrm{mg} / \mathrm{L}, \mathrm{O}_{2}$ was injected until reaching $10.0 \mathrm{mg} / \mathrm{L}$.

For the analysis of blood parameters, six to eight fish were randomly selected at the end of each treatment, control, and corresponding replica. For sampling, the fish were anesthetised with Aqui-S. Then, blood was collected with $1 \mathrm{~mL}$ heparinized needles via caudal punctures. The blood samples were quickly placed in a CG8+ cartridge and analysed by the i-STAT equipment (Abbot) to quantify the blood levels of $\mathrm{Na}^{+}, \mathrm{K}^{+}, \mathrm{Cl}^{-}, \mathrm{pH}, \mathrm{PCO}_{2}, \mathrm{HCO}_{3}$, and glucose. The obtained measurements were corrected for temperature using previously described equations (Hosfeld et al 2008, Gallagher et al 2010, Merkin et al 2010).

\section{STATISTICAL ANALYSIS}

The physicochemical parameters of water are represented as the mean \pm SD of 2-3 samples. Blood parameters are represented as the mean \pm SE of 6-8 fish. The results were statistically evaluated using Statistica v7.0 for Windows. Prior to analyses, the data were evaluated for normality and homogeneity of variance. Then, a two-way analysis of variance was performed, where the independent variables were the control, the CS and OS conditions, and the exposure time to each treatment. In turn, the dependent variables were the salinity, $\mathrm{pH}$ oxygen and $\mathrm{CO}_{2}$ concentrations in the water and the blood levels of glucose, $\mathrm{Na}^{+}, \mathrm{K}^{+}, \mathrm{pH}$, $\mathrm{Cl}^{-}, \mathrm{PCO}_{2}$, and $\mathrm{HCO}_{3}$. A posterior Tukey test was used to evaluate the differences between groups 


\section{RESULTS}

Regarding the physicochemical properties of the water, no significant differences were observed in the $\mathrm{O}_{2}$ levels for any of the treatments as compared to the controls ( $\mathrm{P}$ $>0.05$, table 1). In the case of the CS treatment group, 20 minutes after the start of the trial, $\mathrm{O}_{2}$ was injected into the tank, but levels never surpassed $9.5-10.0 \mathrm{mg} / \mathrm{L}$, maintaining the same conditions as the remaining groups. Significant differences $(\mathrm{P}<0.05)$ were observed between the $\mathrm{CO}_{2}$ levels of the control groups and treatment salt bath groups at both one and two hours. Specifically the traditional CS baths (figure 1A) evidenced a significant increase in $\mathrm{CO}_{2}$ levels, surpassing the critical levels (10 $\mathrm{mg} / \mathrm{L}$ ) for salmonids (Tang et al 2009) in the two hour treatment group. In contrast, the $\mathrm{CO}_{2}$ levels of the OS treatment groups (figure 1B) were slightly increased but remained well below critical levels for all treatment times.
The $\mathrm{pH}$ levels of the water did not show significant differences against the control $(\mathrm{P}>0.05)$, with values between 6.6 and 6.1 in the CS treatment groups (table 1). Furthermore, no significant differences $(\mathrm{P}>0.05)$ in water salinity were found between the CS and OS treatment groups $(15.2 \mathrm{~g} / \mathrm{L}$; table 1$)$. The control group, with no salt, presented a salinity of $0.06 \mathrm{~g} / \mathrm{L}$.

The plasmatic parameters of $\mathrm{Na}^{+}$did not present significant differences between the treatment and control groups (figure 2A). A similar result was found for the blood levels of $\mathrm{Cl}^{-}$, which also showed no significant differences between groups (figure 2B). Additionally, the average levels of $\mathrm{K}^{+}$in the blood were $3.42 \pm 1.36 \mathrm{mmol} / \mathrm{L}$, with no significant differences between the treatment and control groups (figure 3 ). Blood $\mathrm{pH}$ did not significantly vary in relation to the control groups, presented average values of $7.16 \pm 0.036$. Glucose levels also did not significantly vary between the treatments and controls (figure 3 ).

Table 1. Average concentration of oxygen, $\mathrm{pH}$ and salinity in the water treatment ponds $( \pm \mathrm{SD})$.

Concentraciones promedio de oxígeno, $\mathrm{pH}$ y salinidad en el agua de estanques en tratamiento ( $\pm \mathrm{DE})$.

\begin{tabular}{|c|c|c|c|c|c|c|c|c|c|c|c|c|}
\hline & \multicolumn{6}{|c|}{ Closed recirculation } & \multicolumn{6}{|c|}{ Open recirculation } \\
\hline & \multicolumn{3}{|c|}{ Control } & \multicolumn{3}{|c|}{ Treatment } & \multicolumn{3}{|c|}{ Control } & \multicolumn{3}{|c|}{ Treatment } \\
\hline & \multicolumn{3}{|c|}{ Time (minutes) } & \multicolumn{3}{|c|}{ Time (minutes) } & \multicolumn{3}{|c|}{ Time (minutes) } & \multicolumn{3}{|c|}{ Time (minutes) } \\
\hline & 0 & 60 & 120 & 0 & 60 & 120 & 0 & 60 & 120 & 0 & 60 & 120 \\
\hline $\begin{array}{l}\text { Dissolved oxygen } \\
(\mathrm{mg} / \mathrm{L})\end{array}$ & $8.2 \pm 0.8$ & $8.3 \pm 1.0$ & $8.7 \pm 0.9$ & $11.3 \pm 1.6$ & $9.9 \pm 2.2$ & $9.4 \pm 1.7$ & $9.5 \pm 0.4$ & $9.1 \pm 0.4$ & $9.3 \pm 0.4$ & $10.0 \pm 0.9$ & $9.5 \pm 0.8$ & $9.1 \pm 0.8$ \\
\hline $\mathrm{pH}$ & $6.4 \pm 0.1$ & $6.3 \pm 0.1$ & $6.3 \pm 0.1$ & $6.3 \pm 0.2$ & $6.1 \pm 0.2$ & $6.1 \pm 0.2$ & $6.6 \pm 0.0$ & $6.5 \pm 0.0$ & $6.5 \pm 0.0$ & $6.3 \pm 0.1$ & $6.2 \pm 0.1$ & $6.2 \pm 0.1$ \\
\hline Salinity (g/L) & $0.06 \pm 0.0$ & $0.06 \pm 0.0$ & $0.06 \pm 0.0$ & $15.2 \pm 0.6$ & $14.8 \pm 0.0$ & $15.1 \pm 0.1$ & $0.06 \pm 0$ & $0.06 \pm 0.0$ & $0.06 \pm 0.0$ & $15.0 \pm 0.0$ & $15.0 \pm 0.0$ & $14.4 \pm 0.1$ \\
\hline
\end{tabular}

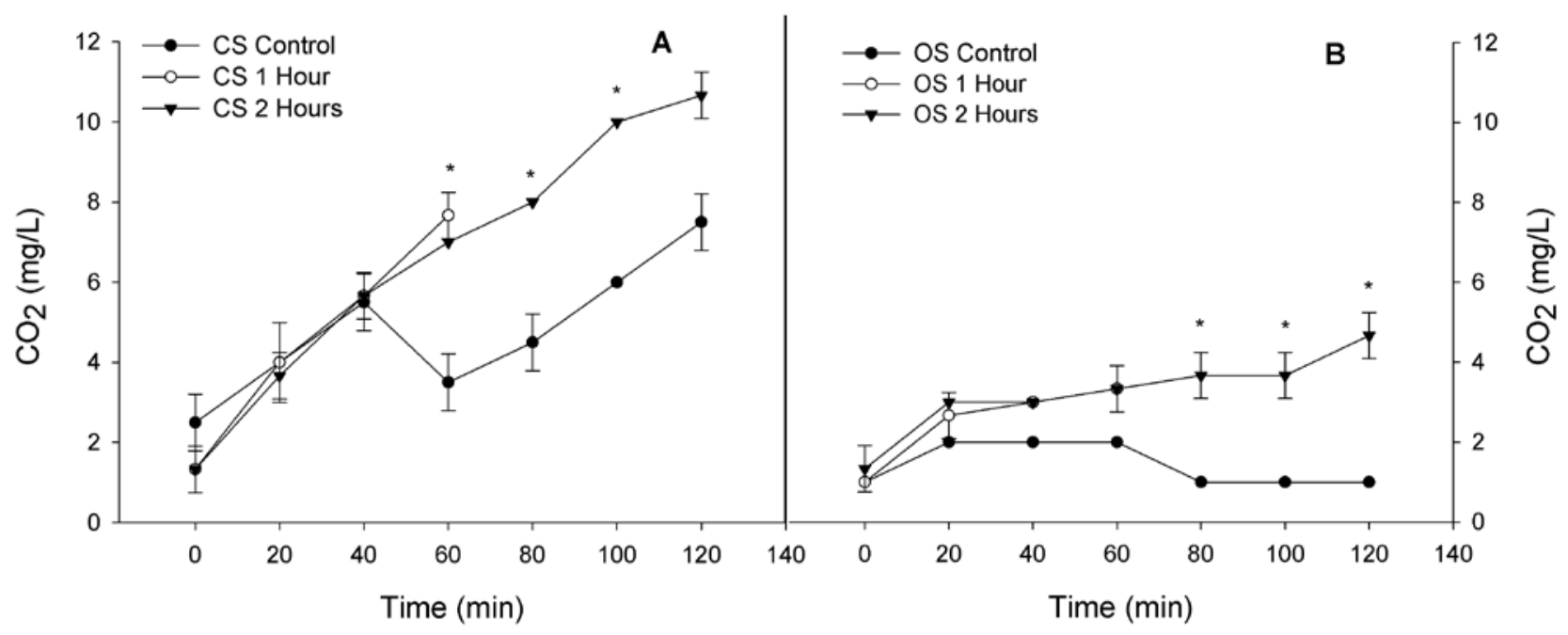

Figure 1. Water concentrations of $\mathrm{CO}_{2}$ over the duration of the salt baths. A) Closed water recirculation system, CS. B) Open water recirculation system, OS. Data represent the mean \pm S.E. * indicates significant differences $(\mathrm{P}<0.05)$ compared to the control.

Concentraciones de $\mathrm{CO}_{2}$ en agua durante el baño de sal. A) Sistema sin recirculación, CS. B) Sistema con recirculación OS. Los datos representan la media $\pm \mathrm{EE} *$ significa diferencias significativas $(\mathrm{P}<0,05)$ respecto del control. 


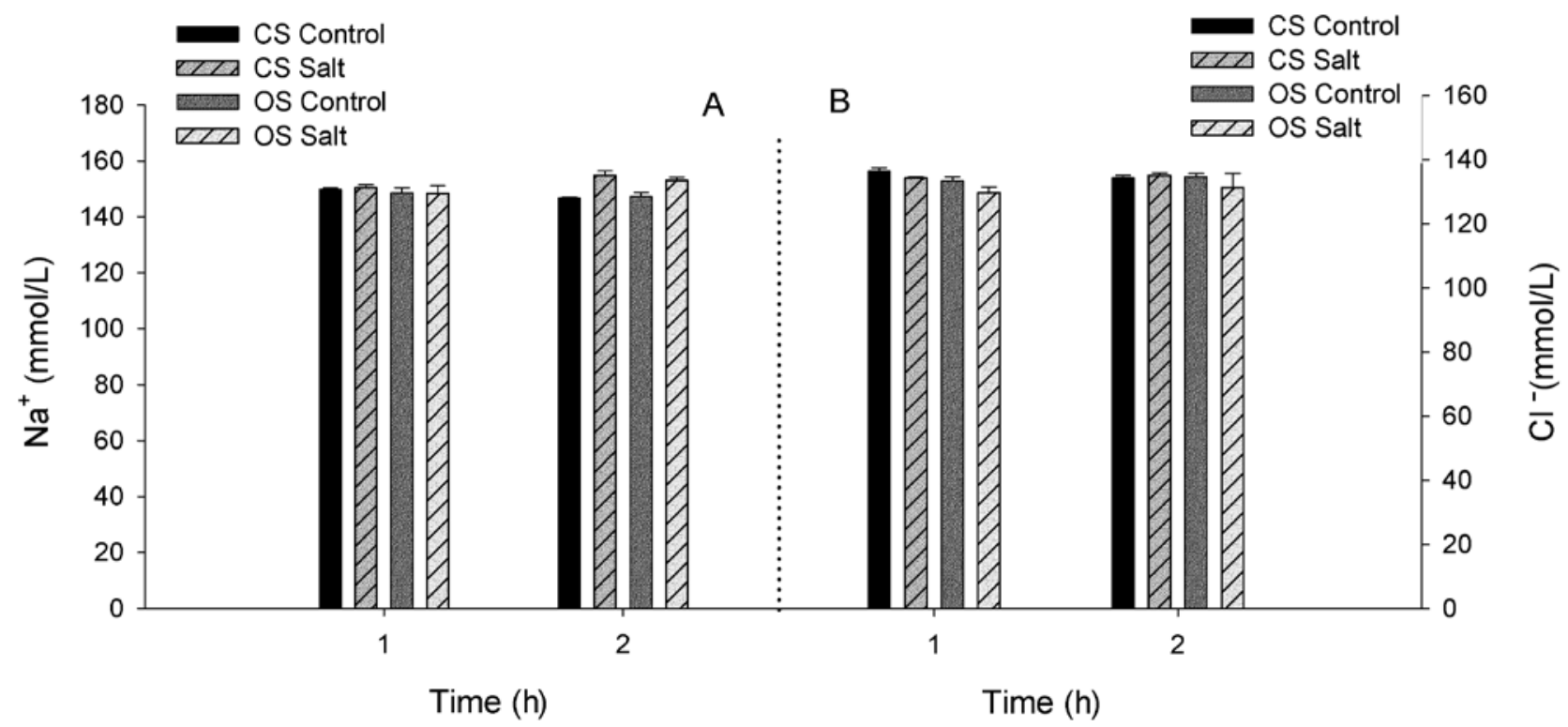

Figure 2. Changes in plasmatic A) $\mathrm{Na}^{+}$levels and $\left.\mathrm{B}\right) \mathrm{Cl}^{-}$levels in fish from closed recirculation (CS) and open recirculation (OS) systems. Data are represented as the mean \pm S.E. of 6-8 fish.

Concentración plasmática de sodio $\left(\mathrm{Na}^{+}\right)$de peces Salmo salar en ambos sistemas sin recirculación (CS) y con recirculación (OS), los datos representan la media \pm E.E.M. de 6 a 8 peces; Concentración plasmática de cloro $\left(\mathrm{Cl}^{-}\right)$de peces Salmo salar en ambos sistemas, sin recirculación $(\mathrm{CS})$ y con recirculación (OS). Los datos representan la media \pm EE de 6 a 8 peces.

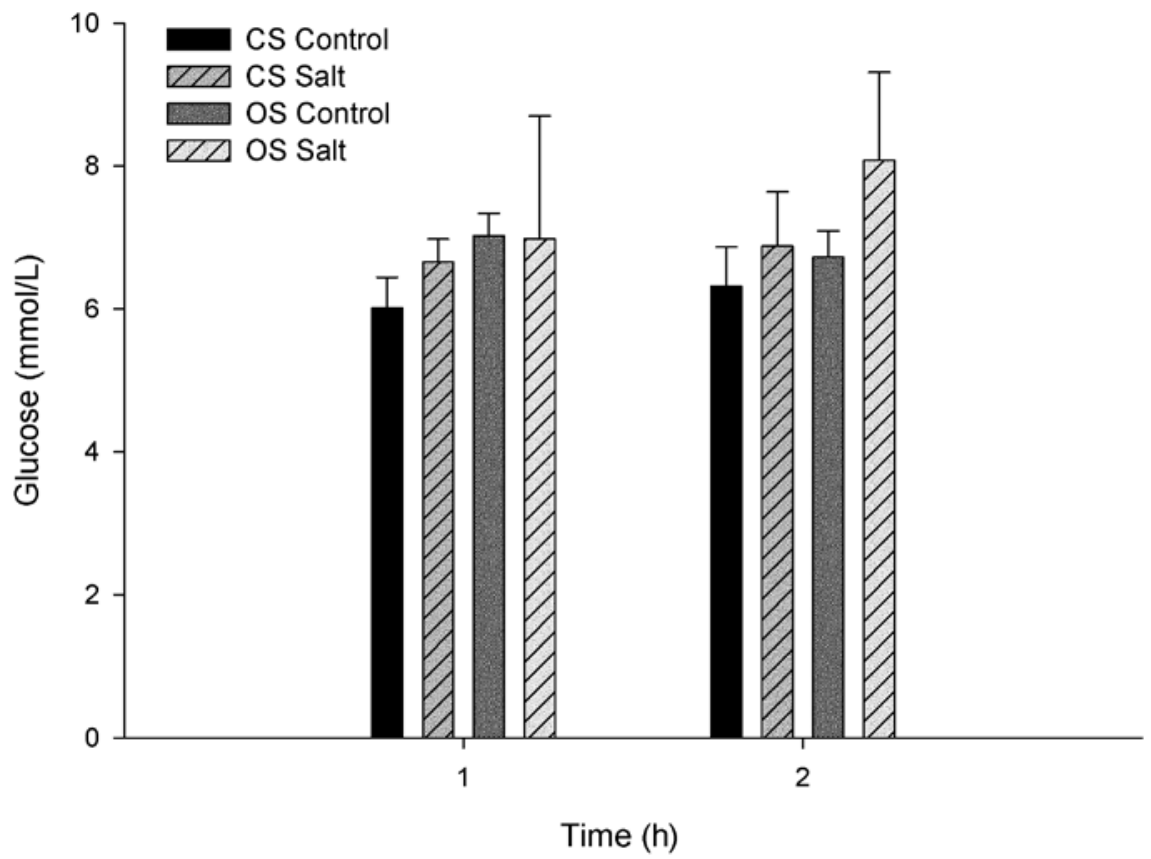

Figure 3. Plasma concentration of glucose fish in both systems; CS without recirculation with recirculation OS. The data represent the mean \pm SE of 6-8 fish.

Concentración plasmática de glucosa de peces Salmo salar en ambos sistemas; Sin recirculación CS, con recirculación OS. Los datos representan la media \pm EE de 6 a 8 peces.

Regarding the blood levels of gases, $\mathrm{PCO}_{2}$ presented significant differences between OS and CS fish, where the $\mathrm{PCO}_{2}$ levels of the two-hour CS treatment group were significantly greater $(\mathrm{P}<0.05)$ than the one-hour CS control group (figure 4). Furthermore, both the treatment and control OS groups had lower $\mathrm{PCO}_{2}$ levels at two hours than the $\mathrm{CS}$ groups, but these differences were not significant.

Fish exposed to a CS salt bath for two hours showed the highest blood levels of $\mathrm{HCO}_{3}$, reaching levels significantly different than the control (figure 5). 


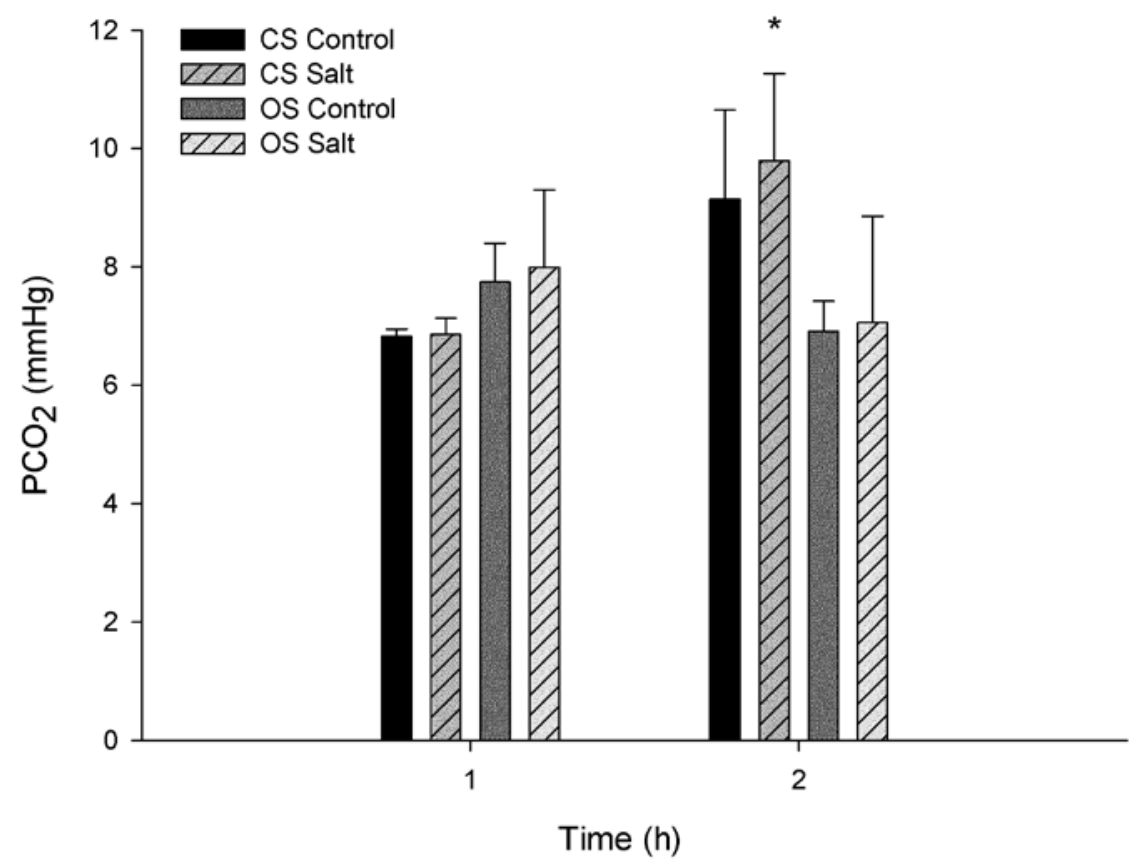

Figure 4. Plasma concentration of $\mathrm{PCO}_{2}$ fish in both systems; $\mathrm{CS}$ without recirculation with recirculation OS. The data represent the mean \pm SE of 6-8 fish. * Indicates significant differences $(\mathrm{P}<0.05)$ compared to control.

Concentración plasmática de $\mathrm{PCO}_{2}$ de peces Salmo salar en ambos sistemas; Sin recirculación CS, con recirculación OS. Los datos representan la media \pm EE de 6 a 8 peces. * Indica diferencias significativas $(\mathrm{P}<0,05)$ respecto del control.

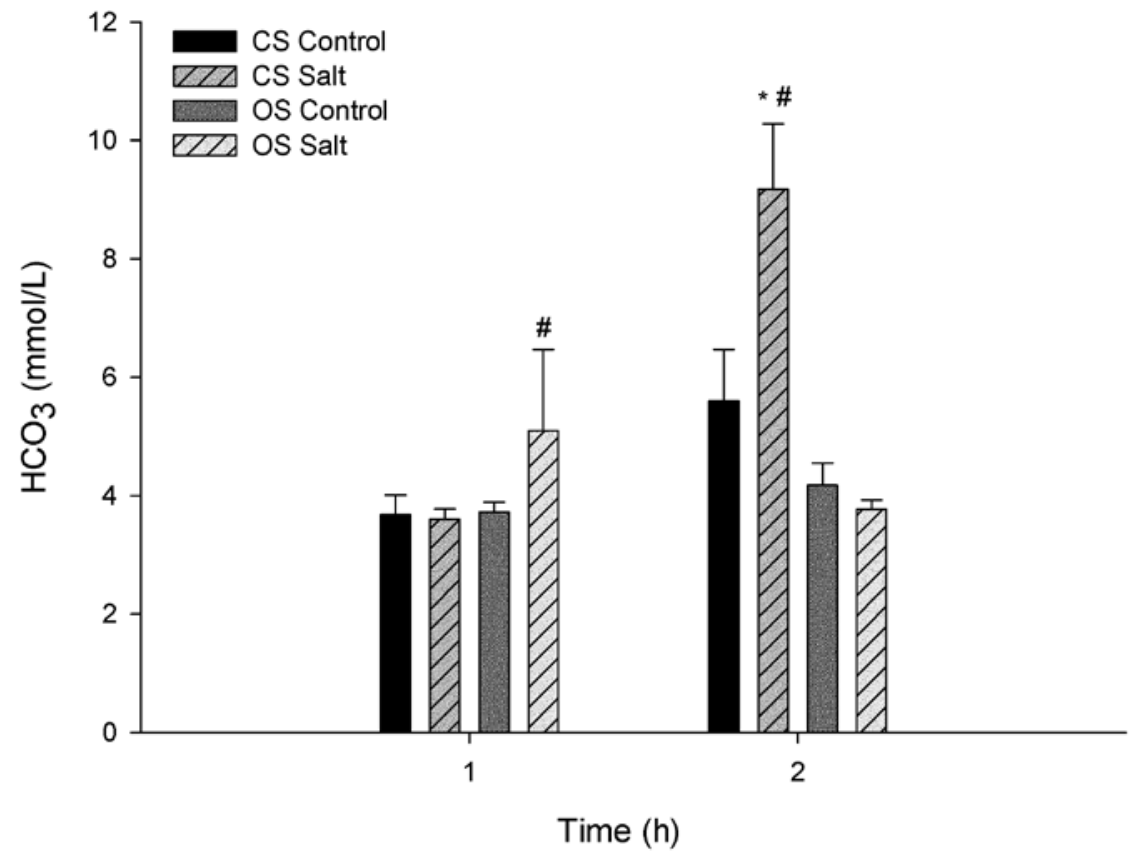

Figure 5. Plasmatic $\mathrm{HCO}_{3}$ variations $n$ fish from closed recirculation (CS) and open recirculation (OS) systems. Data are represented as the mean \pm S.E. of 6-8 fish. * indicates significant differences $(\mathrm{P}<0.05)$ compared to the control; \# indicates significant differences $(\mathrm{P}<0.05)$ between systems.

Variación de los niveles plasmáticos de $\mathrm{HCO}_{3}$ de peces Salmo salar en ambos sistemas; Sin recirculación CS, con recirculación OS. Los datos representan la media \pm E.E.M. de 6 a 8 peces. * significa diferencias significativas $(\mathrm{p}<0,05)$ respecto del control, \# significa diferencias significativas $(\mathrm{P}<0,05)$ entre sistemas. 


\section{DISCUSSION}

Salt baths alter physiological functions, such as metabolism and osmoregulation, in fish (Burgdorf-Moisuk et al 2011). These alterations are associated with increased respiration, as observed in the present study through the rapid uptake of $\mathrm{O}_{2}$ and significant increase in $\mathrm{CO}_{2}$ in the water of salt bath-treated groups (figure 1, table 1). Specifically, the $\mathrm{CO}_{2}$ levels recorded for the water of the two-hour CS treatment group reached $12 \mathrm{mg} / \mathrm{L}$, and $\mathrm{CO}_{2}$ levels between 12 and $30 \mathrm{mg} / \mathrm{L}$ have been found to affect the growth, conversion rate, and immune status of $S$. salar (Smart et al 1979, Wedemeyer 1996, Fivelstad et al 1998). Wedemeyer (1996) suggested that salmonids can tolerate $\mathrm{CO}_{2}$ levels up to $40 \mathrm{mg} / \mathrm{L}$ during transport or over short periods (Tang et al 2009). In contrast, the control OS and CS groups did not surpass $\mathrm{CO}_{2}$ levels of $4 \mathrm{mg} / \mathrm{L}$, which were nearly basal as compared to the CS treatment groups. Importantly, as individual factors, salt and a CS were able to significantly increase the $\mathrm{CO}_{2}$ levels in water, as evidenced by the lower $\mathrm{CO}_{2}$ levels in both the $\mathrm{CS}$ and OS control groups (figure 1). The increased $\mathrm{CO}_{2}$ levels in the treatment groups likely represent a stress response due to increased salinity. This would be in agreement with that reported by Morgan and Iwama (1991), who found that a sudden increase in salinity is related to increased metabolic costs and, consequently, greater oxygen uptake.

The oxygen levels in water were variable for both the control and treatment groups. In the case of the CS groups, the oxygen levels decreased to $7.5 \mathrm{mg} / \mathrm{L}$ after 20 minutes, requiring the injection of oxygen to maintain levels near $10 \mathrm{mg} / \mathrm{L}$. The OS treatment group permitted a greater exchange of gases between the water and air, thus effectively reducing $\mathrm{CO}_{2}$ excess while naturally increasing the availability of oxygen. Ultimately, this would result in better respiration for the fish, thereby reducing physical stress and facilitating better adaptation to salt baths.

The levels of $\mathrm{Na}^{+}$and $\mathrm{Cl}^{-}$in the plasma are relevant indicators of ion transfer through the gills, and changes in these levels represent the first response of a fish when the respiratory regulation of the acid-base balance becomes limited (Perry and Gilmour 2006). For example, rainbow trout (Oncorhynchus mykiss) evidence significantly increased plasma $\mathrm{Na}^{+}$levels when exposed to conditions of hypercapnia, or high levels of $\mathrm{CO}_{2}$ (Larsen and Jensen 1997). The results of the present study did not reflect changes in plasmatic $\mathrm{Na}^{+}$, which might be due to the short exposure period to hypercapnia conditions. Regarding $\mathrm{Cl}^{-}$, plasmatic $\mathrm{Cl}^{-}$levels are reduced as a result of an electro-neutral exchange of ions with $\mathrm{HCO}_{3}$, resulting in a relationship between plasmatic $\mathrm{Cl}^{-}$levels and $\mathrm{HCO}_{3}$ synthesis (Lloyd and White 1967, Fivelstad et al 2003, Hosfeld et al 2008, Fivelstad et al 2015). Contrasting these prior studies, the present results did not evidence this positive relationship, which could, once again, be due to the short experimental period evaluated.
Likewise, blood glucose levels did not significantly vary between the currently assessed treatment and control groups. However, glucose levels in the CS treatment groups were slightly elevated as compared to the control groups for both evaluated time periods. In goldfish, one-hour salt baths at a concentration of $20 \mathrm{~g} / \mathrm{L}$ modify plasmatic glucose levels (Burgdorf-Moisuk et al 2011). The present study was performed under field conditions and in water with controlled oxygen levels, which is noteworthy considering the possible relationship between blood glucose levels and plasmatic oxygen levels (Perry et al 1989).

It is very important to highlight that blood $\mathrm{pH}$ did not present significant variations between the assessed groups, suggesting an internal adaptation of fish to an acute period of stress. If plasmatic $\mathrm{pH}$ falls and respiratory acidosis occurs, rainbow trout are able to compensate for a period of 48-72 hours, while Atlantic salmon can compensate for 24-96 hours. One way in which salmonids adapt to $\mathrm{pH}$ variation is by increasing blood levels of $\mathrm{HCO}_{3}$, which consequently promotes $\mathrm{CO}_{2}$ transport in the blood (Foss et al 2007).

The recorded blood concentrations of $\mathrm{HCO}_{3}$ and $\mathrm{PCO}_{2}$ reflect the physicochemical parameters of the water, where a relationship was found between plasmatic $\mathrm{HCO}_{3}$ and water $\mathrm{CO}_{2}$ levels in both the OS and CS treatment conditions. This relationship is due to the high permeability of the gills to $\mathrm{CO}_{2}$, and in conditions of hypercapnia, rapid internal equilibration occurs by elevating the levels of $\mathrm{PCO}_{2}$ in the blood and tissues (Tang et al 2009). Once internalised, $\mathrm{CO}_{2}$ is rapidly transformed by the enzyme carbonic anhydrase into carbonic acid $\left(\mathrm{H}_{2} \mathrm{CO}_{3}\right)$, resulting in blood acidosis. Furthermore, studies have found that prolonged hypercapnia leads to increased blood levels of $\mathrm{PCO}_{2}$, activating the primary stress response in fish (Perry et al 1989) and leading to changed $\mathrm{pH}$ levels (Eddy et al 1977, Thomas and Le Ruz 1982), increased respiratory volume and rate (Janssen and Randall, 1975, Thomas et al 1983, Fivelstad et al 1999)PWCO $2=5$ TorrPWO 2=400\ u2013450 TorrSalmo gairdneri R.9934lluc0॥lu8211\{\}36, reduced $\mathrm{O}_{2}$ levels, and variations in transport ability through the Bohr and Root effects (Eddy and Morgan 1969, Eddy et al 1977, Wedemeyer 1996).

Blood $\mathrm{pH}$ was not significantly affected, indicating that the assessed fish did not suffer prolonged hypercapnia. However, $\mathrm{HCO}_{3}$ and $\mathrm{PCO}_{2}$ levels were significantly affected, evidencing moderate hypercapnia, the effects of which were offset by the fish. Among the adaptation strategies of fish to hypercapnia exposure are increased ventilation and the use of chemosensors on the periphery of the gills that monitor environmental $\mathrm{CO}_{2}$ levels (Burleson and Smatresk 2000, Reid et al 2000, Gilmour 2001, Perry and McKendry 2001). These chemosensors are only stimulated by changes in the water concentration of $\mathrm{CO}_{2}$ and not by changes in pH (Perry and McKendry 2001).

Salt baths administered with an open recirculation system did not significantly affect the physicochemical parameters 
of the water as compared to the untreated control group. In contrast, salt baths administered with a closed recirculation system resulted in increased water $\mathrm{CO}_{2}$ concentrations. Likewise, the two-hour, closed recirculation treatment group showed significantly affected blood parameters (i.e. $\mathrm{PCO}_{2}$ and $\mathrm{HCO}_{3}$ ) as compared to the respective control. These changes resulted in moderate hypercapnia, directly affecting animal welfare in culture conditions.

\section{ACKNOWLEDGEMENTS}

The authors thank Joachim Wessel, Francisco Vallejos, and Bruno Pavez of Salmones FrioSur S.A., Internal Salt Bath Improvement Program. This study was supported by the CONICYT Academic Insertion Grant $\mathrm{N}^{\circ} 7912010009$ and by FONDECYT Grant $\mathrm{N}^{\circ} 11121498$. The authors also thank the constructive comments of the reviewers, which improved the overall quality of this manuscript.

\section{REFERENCIAS}

Auro de Ocampo A, L Ocampo-Camberos. 1999. Diagnóstico del estrés en peces. Vet Méx 30, 337-344.

Avendaño R. 2012. Enfermedades infecciosas del cultivo de salmónidos en Chile y el mundo. NIVA SA, Chile. Pp 77-104.

Burleson ML, NJ Smatresk. 2000. Branchial chemoreceptors mediate ventilatory responses to hypercapnic acidosis in cannel catfish. Comp Biochem Physiol A 125, 403-414.

Burgdorf-Moisuk A, MA Mitchell, M Watson. 2011. Clinical and physiologic effects of sodium chloride baths in goldfish (Carassius auratus). J Zoo Wild Med 42, 586-592.

Dhabhar FS. 2009. A hassle a day may keep the pathogens away: the fight-or-flight stress response and the augmentation of immune function. Integr Comp Biol 49, 215-236

Eddy FB, RIG Morgan. 1969. Some effects of carbon dioxide on blood of rainbow trout Salmo gardneri Richardson. J Fish Biol 1, 361-372.

Eddy FB, JP Lomholt, RE Weber, K Johansen. 1977. Blood respiratory properties of rainbow trout (Salmo gairdneri) kept in water oh high $\mathrm{CO} 2$ tension. J Exp Biol 67, 37-47.

Fivelstad S, H Haavik, G Lovik, AB Olsen. 1998. Sublethal effects and safe levels of carbon dioxide in seawater for atlantic salmon postsmolts (Salmo salar L.): ion regulation and growth. Aquaculture 160, 305-316.

Fivelstad S, AB Olsen, H Kløften, H Ski, S Stefansson. 1999. Effects of carbon dioxide on Atlantic salmon (Salmo salar L.) smolts at constant $\mathrm{pH}$ in bicarbonate rich freshwater. Aquaculture 178, 171-177.

Fivelstad S, AB Olsen, T Asgard, G Baeverfjord, T Rasmussen, $\mathrm{T}$ Vindheim, S Stefansson. 2003. Long-term sublethal effects of carbon dioxide on Atlantic salmon smolts (Salmo salar L.): ion regulation, haematology, element composition, nephrocalcinosis and growth parameters. Aquaculture 215, 301-319.

Fivelstad S, K Kvamme, S Handeland, M Fivelstad, AB Olsen, CD Hosfeld. 2015. Growth and physiological models for Atlantic salmon (Salmo salar $L$.) parr exposed to elevated carbon dioxide concentrations at high temperature. Aquaculture 436, 90-94.

Foss A, AK Imsland, B Roth, E Schram, SO Stefansson. 2007. Interactive effects of oxygen saturation and ammonia on growth and blood physiology in juvenile turbot. Aquaculture 271, 244-251.

Gallagher AJ, LH Frick, PG Bushnell, RW Brill, JW Mandelman. 2010. Blood gas, oxygen saturation, $\mathrm{pH}$, and lactate values in Elasmobranch blood measured with a commercially available portable clinical analyzer and standard laboratory instruments. J Aquat Anim Health 22, 229-234.

Gesto M, MA López-Patiño, J Hernández, JL Soengas, JM Míguez. 2013. The response of brain serotonergic and dopaminergic systems to an acute stressor in rainbow trout: a time course study. J Exp Biol 216, 4435-4442.

Gilmour KM. 2001. The CO2/pH ventilation drive in fish. Comp Biochem Physiol A130, 219-240.

Hastein T. 2004. Animal welfare issues relating to aquaculture. OIE Global Conference on Animal Welfare, Paris, France, Pp 219-227.

Hosfeld CD, A Engevik, T Mollan, TM Lunde, R Waagbo, AB Olsen, O Breck, S Stefansson, S Fivelstad. 2008. Long-term separate and combined effects of environmental hipercapnia and hiperoxia in Atlantic salmon (Salmo salar L.) smolts. Aquaculture 280, 146-153.

Janssen RG, DJ Randall. 1975. Effects of changes in pH and PCO2 in blood and water on breathing in rainbow trout, Salmo gairdneri. Resp Physiol 25, 235-245.

Kestin S. 1994. Pain and stress in fish. Report for the Royal Society for the Prevention of Cruelty to Animals (RSPCA). RSPCA, West Sussex, UK.

Larsen BK, FB Jensen. 1997. Influence of ionic composition on acidbase regulation in rainbow trout (Oncorhynchus mykiss) exposed to environmental hypercapnia. Fish Physiol Biochem 16, 157-170.

Lloyd R, WR White. 1967. Effect of high concentration of carbon dioxide on the ionic composition of rainbow trout blood. Nature 216, 1341-1342.

Merkin GV, B Roth, C Gjerstad, E Dahl-Paulsen, R Nortvedt. 2010. Effect of pre-slaughter procedures on stress responses and some quality parameters in sea-farmed rainbow trout (Oncorhynchus mykiss). Aquaculture 309, 231-235.

Mifsud C, SJ Rowland. 2008. Use of salt to control ichthyophthiriosis and prevent saprolegniosis in silver perch, Bidyanus bidyanus. Aquac Res 39, 1175-1180.

Morgan JD, GK Iwama. 1991. Effects of salinity on growth, metabolism and ion regulation in juvenile rainbow and steelhead trout (Oncorhynchus mykiss) and fall chinook salmon (Oncorhynchus tshawytscha). Can J Fish aquat Sci 48, 2083-2094.

Perry SF, R Kinkead, P Gallaugher, DJ Randall. 1989. Evidence that hipoxemia promotes catecholamine release during hypercapnic acidosis in rainbow trout (Salmo gairdneri). Resp Physiol 77, 351-363.

Perry SF, JE McKendry. 2001. The relative roles of external and internal $\mathrm{CO} 2$ versus $\mathrm{H}+$ in eliciting the cardiorespiratory responses of Salmo salar and Squalus acanthias to hypercarbia. J Exp Biol 204, 3963-3971.

Perry SF, KM Gilmour. 2006. Acid-base balance and CO2 excretion in fish: Unanswered questions and emerging models. Respir Physiol Neurobiol 154, 199-215.

Polakof S, FJ Arjona, S Sangiao-Alvarellos, MP Martín del Río, JL Soengas. 2006. Food deprivation alters osmoregulatory and metabolic responses to salinity acclimation in gilthead sea bream Sparus auratus. J Comp Physiol B 176, 441-452.

Rasowo J, OE Okoth, CC Ngugi. 2007. Effects of formaldehyde, sodium chloride, potassium permanganate and hydrogen peroxide on hatch rate of African catfish Clarias gariepinus eggs. Aquaculture 26, 271-277.

Reid SG, L Sundin, AL Kalinin, FT Rantin, WK Milson. 2000. Cardiovascular and respiratory reflexes in the tropical fish, traira (Hoplias malabaricus): $\mathrm{CO} 2 / \mathrm{pH}$ chemoresponses. Respir Physiol 120, 47-59.

Smart GR, D Knox, JG Harrison, JA Ralph, RH Richards, CB Cowey. 1979. Nephrocalcinosis in rainbow trout Salmo gairdneri Richardson; the effect of exposure to elevated $\mathrm{CO} 2$ concentration. J Fish Dis 2, 279-289.

Tang S, H Thorarensen, CJ Brauner, CM Wood, AP Farrell. 2009. Modeling the accumulation of $\mathrm{CO} 2$ during high density, re-circulating transport of adult Atlantic salmon, Salmo salar, from observations aboard a sea-going commercial live-haul vessel. Aquaculture 296, 102-109.

Thomas PM, NW Pankhurst, HA Bremner. 1999. The effect of stress and exercise on post-mortem biochemistry of Atlantic salmon ad rainbow trout. J Fish Biol 54, 1177-1196.

Thomas S, H Le Ruz. 1982. A continuous study of rapid changes in blood acid-base-status of trout during variations of water PCO2. J Comp Physiol B 148, 123-130. 
Thomas S, B Fievet, L Barthelemy, C Peyraud. 1983. Comparison of the effects of exogenous and endogenous hipercapnia on ventilation and oxygen-uptake in the rainbow trout (Salmo gairdneri R.). J Comp Physiol B 151, 185-190.

Tort L. 2011. Stress and immune modulation in fish. Dev Com Immunol 35, 1366-1375.

Van West P. 2006. Saprolegnia parasítica, an oomycete pathogen with a fishy appetite: new challenges for an old problem. Mycologist 20,99-104.

Vargas-Chacoff L, D Martínez, R Oyarzún, D Nualart, V Olavarría, A Yáñez, C Bertrán, I Ruiz-Jarabo, JM Mancera. 2014. Combined effects of high stocking density and Piscirickettsia salmonis treatment on the immune system, metabolism and osmoregulatory responses of the Sub-Antarctic Notothenioid fish Eleginops maclovinus. Fish Shellfish Immunol 40, 424-434.

Wangen K. 2012. Therapeutic review: Sodium Chloride. J Exot Pet Med 21, 94-98.

Wedemeyer GA. 1996. Physiology of Fish in Intensive Culture Systems. Chapman \& Hall, New York, USA, Pp 60-109.

Wendelaar Bonga SE. 1997. The stress response in fish. Phisiol Rev 77, 1-39. 